\title{
Experimental Studies on the Biokinetics of Plutonium and Americium in the Cephalopod Octopus vulgaris
}

\author{
Jean-Claude Guary* and Scott W. Fowler \\ International Laboratory of Marine Radioactivity, Musée Océanographique, Principality of Monaco
}

\begin{abstract}
Radiotracer experiments using the photon-emitters ${ }^{237} \mathrm{Pu}$ and ${ }^{241} \mathrm{Am}$ were performed to examine uptake, tissue distribution and retention of plutonium and americium in the cephalopod Octopus vulgaris Cuvier. A 2 wk exposure in contaminated sea water resulted in twice as much ${ }^{237} \mathrm{Pu}$ being taken up by whole octopus as ${ }^{241} \mathrm{Am}$. Immediately following uptake approximately $41 \%$ and $73 \%$ of the ${ }^{237} \mathrm{Pu}$ and ${ }^{241} \mathrm{Am}$ respectively were located in the branchial hearts. Depuration rates for both radionuclides were identical; approximately $46 \%$ of both radionuclides initially incorporated were associated with a long-lived compartment which turned over very slowly $\left(\mathrm{Tb}_{1 / 2}=1.5 \mathrm{yr}\right)$. Longer exposures to ${ }^{241} \mathrm{Am}$ resulted in an increase in the size of the slowly exchanging ${ }^{241} \mathrm{Am}$ pool in the octopus. After 2 mo depuration, the majority of the residual activity of both radionuclides was in the branchial hearts. On average $33 \%$ of the ${ }^{241} \mathrm{Am}$ ingested with food was assimilated into tissues, primarily the hepatopancreas. Different whole-body ${ }^{241}$ Am excretion rates were observed at different times following assimilation and were related to transfer processes taking place within internal tissues, most notably between hepatopancreas and the branchial hearts. Relationships between circulatory and excretory functions of these 2 organs are discussed and a physiological mechanism is proposed to explain the observed patterns of ${ }^{241} \mathrm{Am}$ excretion in O. vulgaris.
\end{abstract}

\section{INTRODUCTION}

Marine invertebrates have been strongly implicated in the biogeochemistry of transuranic elements, particularly plutonium and americium (Beasley and Cross, 1980). The common octopus, Octopus vulgaris Cuvier, is a benthic cephalopod which occupies a top predatory level in the marine food chain. Moreover, this invertebrate is of particular interest in ecological studies because of its advanced physiology, its lack of shell and the fact that it is widely distributed throughout the coastal zone, the principal marine region receiving pollutants at present.

Data have been reported recently which show in certain tissues of this mollusc high concentrations of ${ }^{239+240} \mathrm{Pu}$ and ${ }^{241} \mathrm{Am}$ (Guary et al., 1981; Miramand and Guary, 1981), other radionuclides such as ${ }^{60} \mathrm{Co}$ (Nakahara et al., 1979) and various heavy metals (Miramand and Guary, 1980). In view of the apparent ability of the

- Present address: Laboratoire de Géologie, Ecole Normale Supérieure, 46 rue d'Ulm, 75230 PARIS Cedex 05, France octopus to concentrate radionuclides to relatively high levels compared to other invertebrates, we undertook a detailed study of the processes involved in the uptake, tissue distribution and retention of plutonium and americium in this species.

\section{MATERIALS AND METHODS}

Young Octopus vulgaris Cuvier were collected from the littoral zone near Monaco and acclimated in running-seawater aquaria until used. The radionuclides ${ }^{237} \mathrm{Pu}\left(\mathrm{T}_{1 / 2}=46 \mathrm{~d}\right)$ and ${ }^{241} \mathrm{Am}\left(\mathrm{T}_{1 / 2}=433 \mathrm{yr}\right)$ were used as radiotracers and were measured by gamma counting techniques with $40 \%$ and $28 \%$ efficiency, respectively (Fowler et al., 1975; Guary and Fowler, 1981). The test animals were introduced into plastic counting tubes which were closed by a stopper weighted with a lead bar. In this way, the organisms were measured regularly for their radioactivity content by whole body gamma-spectrometry. Corrections were made for phys- 
ical decay of ${ }^{237} \mathrm{Pu}$ and for the different geometries employed.

\section{Accumulation from Seawater}

Four cephalopods, ranging in wet weight from 80 to $140 \mathrm{~g}$, were transferred to closed plastic buckets containing $4 \mathrm{l}$ of cotton-filtered sea water, aerated and maintained at $13^{\circ} \pm 1 \mathrm{C}^{\circ}$. Two media were spiked with ${ }^{237} \mathrm{Pu}$ (III-IV oxidation state) at a concentration of $0.74 \mathrm{kBq}(20 \mathrm{nCi}) \mathrm{l}^{-1}$ and the other 2 with ${ }^{241} \mathrm{Am}$ (III oxidation state) at $1.1 \mathrm{kBq}(30 \mathrm{nCi}) \mathrm{l}^{-1}$. Throughout the $15 \mathrm{~d}$ exposure period, the buckets were refilled daily with freshly labelled sea water at the same concentration in order to reduce the possibility of complexation between the isotopes and excreted metabolites (Fowler et al., 1975) and to maintain the radiotracer concentrations relatively constant. The cephalopods were not fed since brief periods of starvation do not appear to debilitate $O$. vulgaris (Wells, 1978). They were periodically removed from the buckets and rinsed for several min in clean seawater; their radioactivity was measured by whole-body counting and expressed as concentration factors $\left(\mathrm{cpm} \mathrm{\textrm {g } ^ { - 1 }}\right.$ wet individual $\div \mathrm{cpm} \mathrm{ml} \mathrm{ml}^{-1}$ seawater). At the end of the experiment, the cephalopods were dissected to determine the concentration and the distribution of ${ }^{237} \mathrm{Pu}$ and ${ }^{241} \mathrm{Am}$ in their tissues

\section{Elimination}

Four cephalopods ( $300-400 \mathrm{~g}$ wet), which had previously accumulated ${ }^{237} \mathrm{Pu}$ and ${ }^{241} \mathrm{Am}$ from seawater for $10 \mathrm{~d}$ under the same conditions as described above, were transferred to $100 \mathrm{l}$ aquaria supplied with running seawater for the depuration phase. The average initial concentration of ${ }^{237} \mathrm{Pu}$ and ${ }^{241} \mathrm{Am}$ in the whole individuals was $25 \mathrm{~Bq}(675 \mathrm{pCi}) \mathrm{g}^{-1}$ wet and $28 \mathrm{~Bq}$ (750 pCi) $\mathrm{g}^{-1}$ wet, respectively. Furthermore, loss of ${ }^{241} \mathrm{Am}$ was followed under the same conditions in a $70-g$ female that had accumulated this radionuclide from seawater for a longer period of time (22 d) and whose initial ${ }^{241} \mathrm{Am}$ whole-body concentration was $56 \mathrm{~Bq}$ (1500 pCi) $\mathrm{g}^{-1}$ wet. Throughout the $70 \mathrm{~d}$ elimination period the cephalopods were fed daily with crabs, weighed, and their radioactivity measured periodically. Whole-body loss of the radionuclide, corrected for physical decay, is expressed as the percentage of the initial radionuclide content in whole individuals at the beginning of the loss experiment. Plutonium-237 and ${ }^{241} \mathrm{Am}$ concentrations and distributions in tissues were determined by dissection at the end of the experiment.

\section{${ }^{241}$ Am Uptake from Food}

Two groups of cephalopods, each of 4 , weighing between 100 and $330 \mathrm{~g}$ wet were fed a single ration of crab (Carcinus maenas) labelled with ${ }^{241} \mathrm{Am}$ by injection through the leg joint. Each cephalopod in the first group was given approximately $18.5 \mathrm{kBq}$ (500 nCi), those in the second group about $15 \mathrm{kBq}$ ( $400 \mathrm{nCi}$ ). Four hours after feeding, the radioactivity ingested was measured by whole-body counting techniques as described above. Then the cephalopods were returned to their $100 \mathrm{l}$ running-seawater aquaria and fed daily with 1 or 2 unlabelled crabs. During the excretion phase, the radioactivity of cephalopods and faeces was monitored regularly to determine the fraction of the original ingested dose retained and to estimate the relative importance of faeces in the total excretion process. In addition, 6 individuals were dissected at various times during the excretion phase to determine the tissue distribution of ingested ${ }^{241} \mathrm{Am}$ and the main sites of absorption. The assimilation coefficients for americium were estimated by resolving the loss components of the radionuclide retention curve (Fowler and Guary, 1977).

\section{RESULTS}

\section{Accumulation}

Accumulation of ${ }^{237} \mathrm{Pu}$ (III + IV) appeared to be more rapid than that of ${ }^{241} \mathrm{Am}$, particularly during the first week (Fig. 1). After 2 wk this tendency was reflected by whole-body concentration factors in the octopus of 65 for ${ }^{237} \mathrm{Pu}$ and 35 for ${ }^{241} \mathrm{Am}$. Concentration factors of both elements were also high in the gills (Table 1), again higher for ${ }^{237} \mathrm{Pu}(900)$ than for ${ }^{241} \mathrm{Am}$ (120). The same was true for the epithelium of the mantle ( 80 for ${ }^{237} \mathrm{Pu}$ and 10 for $\left.{ }^{241} \mathrm{Am}\right)$. By far the highest concentration factors were found in the branchial hearts, 9300 and 7100 for plutonium and americium respectively. All the other organs (kidney, gonads, digestive tract) concentrated plutonium and americium to approximately the same level (10-20). The hepatopancreas, although displaying much lower concentration factors, took up twice as much ${ }^{237} \mathrm{Pu}(50)$ as ${ }^{241} \mathrm{Am}(20)$, and the muscle almost 5 times as much.

After $2 \mathrm{wk}$, much of the ${ }^{237} \mathrm{Pu}(41 \%)$ and most of the ${ }^{241} \mathrm{Am}(73 \%)$ were essentially fixed in the branchial hearts, internal circulatory and excretory organs that comprise only $0.3 \%$ of the total body weight. The gills which rapidly took up the 2 radionuclides contained 18.3 and $3.8 \%$ of the ${ }^{237} \mathrm{Pu}$ and ${ }^{241}$ Am respectively. The other internal organs (hepatopancreas, gonads, kidney, digestive tract) taken collectively fixed only a 


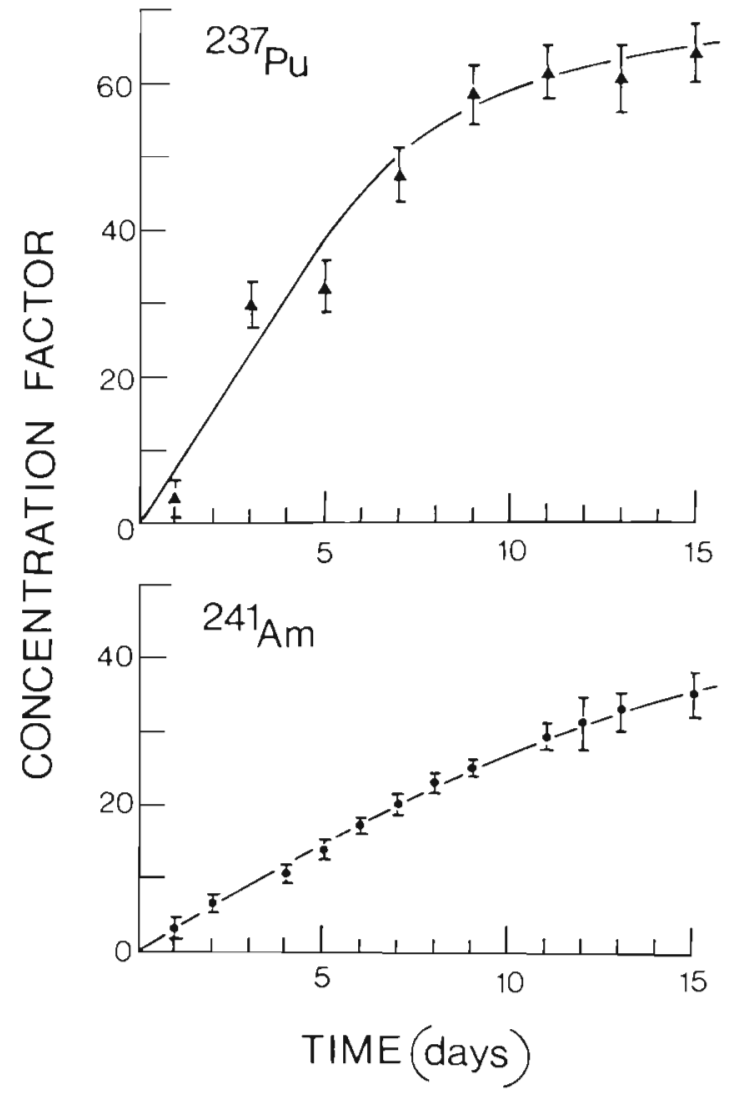

Fig. 1. Octopus vulgaris. Accumulation of ${ }^{237} \mathrm{Pu}$ and ${ }^{241} \mathrm{Am}$ from sea water. Each symbol represents mean and range of 2 individuals

very small proportion of the total ${ }^{237} \mathrm{Pu}(2.9 \%)$ and ${ }^{241} \mathrm{Am}(3.1 \%)$. On the other hand, a substantial fraction of these radionuclides ( 33 and $19 \%$ respectively) was associated with the epithelium and muscles of the tentacles and the cephalic body, tissues which constitute about $80 \%$ of the weight of the cephalopod.

\section{Elimination}

Whole-body loss of ${ }^{237} \mathrm{Pu}$ and ${ }^{241} \mathrm{Am}$ from Octopus vulgaris during a $70 \mathrm{~d}$ period is depicted in Fig. 2. The data represent the percentage retained of the initial ${ }^{237} \mathrm{Pu}$ or ${ }^{241} \mathrm{Am}$ content in whole individuals at the beginning of the experiment. It appears that the loss rates of the 2 transuranic elements are identical after a $10 \mathrm{~d}$ accumulation period (Fig. 2, Curve 1). Inspection of Curve 1 indicates that elimination was taking place from at least 2 compartments. The compartments were resolved by using the standard kinetic approach of Comar (1955), and the long-lived compartment was fitted by a least-squares regression between Day 8 and 70. This radionuclide pool contained approximately $46 \%$ of the incorporated radioactivity which turned over very slowly with a biological half-life of $560 \mathrm{~d}$. The curve also indicates the presence of at least one short-lived compartment which contains roughly $30 \%$ of the radionuclides but turns over very rapidly $\left(\mathrm{Tb}_{1 / 2} \sim\right.$ $2 \mathrm{~d})$. Curve 2 shows that after a longer exposure ( $22 \mathrm{~d}$ ), the octopus tends to lose ${ }^{241} \mathrm{Am}$ more slowly $\left(\mathrm{Tb}_{1 / 2}=\right.$ $680 \mathrm{~d})$. In this case, it is noteworthy that the long-lived compartment contained a higher proportion $(90 \%)$ of the initially incorporated ${ }^{241} \mathrm{Am}$.

The residual radioactivity in whole octopus after $70 \mathrm{~d}$ of loss still represented more than $40 \%$ of the initial body burden in one case (Fig. 2, Curve 1) and greater than $80 \%$ following the longer exposure (Fig. 2, Curve 2). At that time, the majority of the ${ }^{237} \mathrm{Pu}$ and ${ }^{241} \mathrm{Am}$ was located in the branchial hearts (Table 2). While greater than $95 \%$ of the initial radioactivity was lost from the other tissues (not shown), the branchial hearts strongly retained both radionuclides. These results suggest to us that the short-lived compartment could represent principally the skin which eliminated the transuranium elements

Table 1. Octopus vulgaris. Concentration factor (CF) and distribution (\%) of ${ }^{237} \mathrm{Pu}$ and ${ }^{241} \mathrm{Am}$ in the tissues after $15-\mathrm{d}$ exposure in contaminated sea water. Two individuals were dissected for each radionuclide and their tissues grouped for radioanalysis. (n.d.: not detectable)

\begin{tabular}{|c|c|c|c|c|c|}
\hline \multirow[t]{2}{*}{ Tissue } & \multirow{2}{*}{$\begin{array}{l}\text { Average } \% \text { total } \\
\text { tissue wet weight }\end{array}$} & \multicolumn{2}{|c|}{${ }^{237} \mathrm{Pu}$} & \multicolumn{2}{|c|}{${ }^{241} \mathrm{Am}$} \\
\hline & & $\mathrm{CF}$ & $\begin{array}{c}\% \text { of total } \\
\text { body burden }\end{array}$ & $\mathrm{CF}$ & $\begin{array}{c}\% \text { of total } \\
\text { body burden }\end{array}$ \\
\hline Branchial hearts and appendages & 0.3 & 9300 & 40.6 & 7100 & 72.8 \\
\hline Hepatopancreas & 2.9 & 50 & 2.2 & 20 & 1.3 \\
\hline Ventricle & 0.2 & n.d. & - & n.d. & - \\
\hline Gonad & $(0.5-1.1)$ & 8 & 0.1 & 9 & 0.1 \\
\hline Kidney & 0.8 & 7 & 0.1 & 20 & 0.5 \\
\hline Digestive tract & 3.2 & 11 & 0.5 & 15 & 1.2 \\
\hline Gill and branchial gland & 1.4 & 900 & 18.3 & 120 & 3.8 \\
\hline \multicolumn{6}{|l|}{ Mantle } \\
\hline - epithelium & 2.4 & 80 & 3.4 & 10 & 0.4 \\
\hline - muscle & 8.2 & 15 & 1.8 & 3 & 0.6 \\
\hline Remainder (arms and cephalic body) & 80.0 & 30 & 33.0 & 8 & 19.3 \\
\hline
\end{tabular}




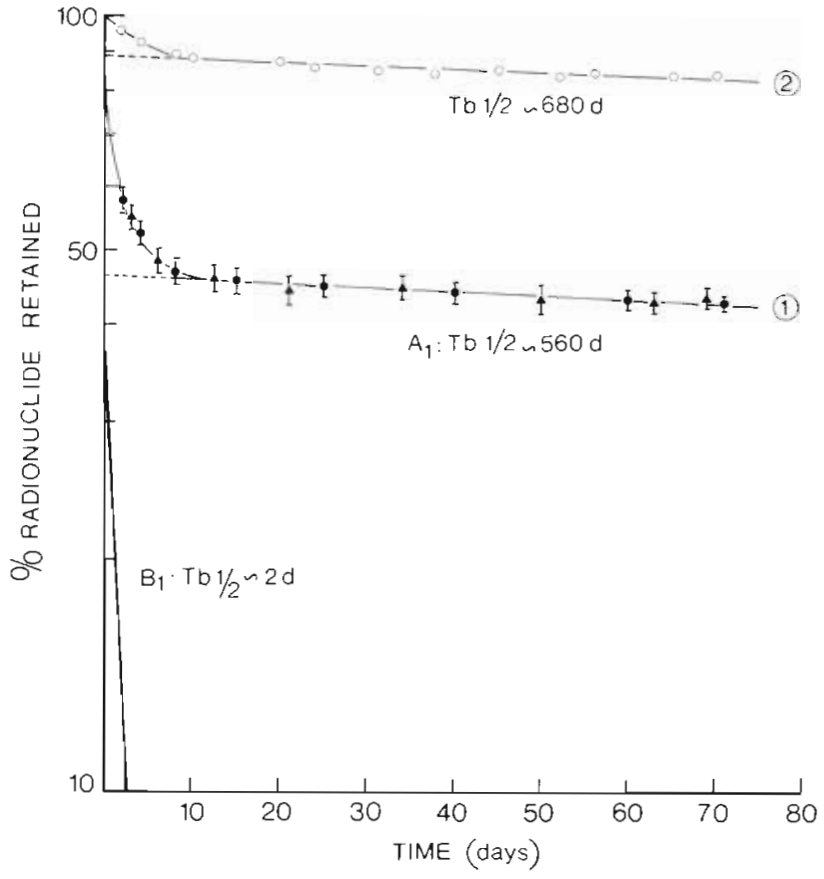

Fig. 2. Octopus vulgaris. Whole body elimination of ${ }^{237} \mathrm{Pu}$ and ${ }^{241} \mathrm{Am}$. Curve 1: loss of ${ }^{237} \mathrm{Pu}$ (4) and ${ }^{241} \mathrm{Am}$ (•) following $10-\mathrm{d}$ exposure in sea water. Points: mean \pm 10 of 4 individuals. Curve 2: loss of ${ }^{241} \mathrm{Am}$ after 22-d exposure in sea water. Point represents a single individual

very rapidly probably by passive desorption. In contrast plutonium and americium, which were incorporated mainly in the branchial hearts, were excreted only very slowly from this tissue which constitutes the major component of the long-lived compartment.

\section{Uptake from Food}

Roughly $65 \%$ of the radioactivity in the labelled crabs was ingested. This resulted in radioactivity

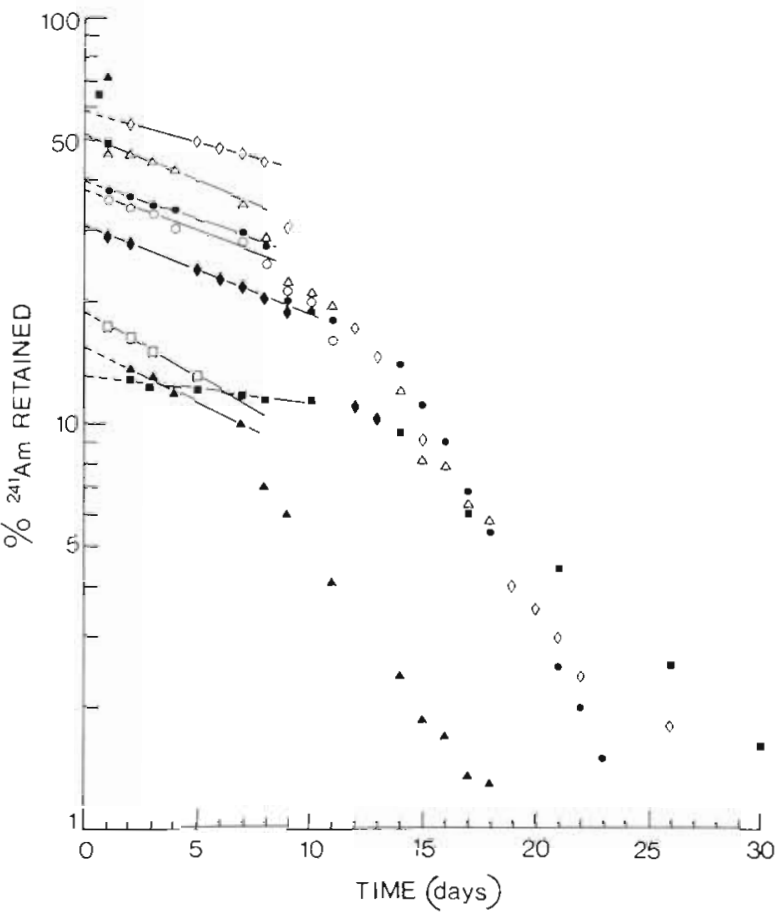

Fig. 3. Octopus vulgaris. Excretion of ${ }^{241} \mathrm{Am}$ following a single ingestion of labelled crab. Each symbol represents the percentage of residual radioactivity in a single individual

levels of approximately $13.0 \pm 4.0 \mathrm{kBq}(350 \mathrm{nCi})$ and $9.0 \pm 0.8 \mathrm{kBq}(240 \mathrm{nCi})$ in the 2 groups of octopus. During the first 24 to $48 \mathrm{~h}$ after ingestion, 30 to $80 \%$ of the ingested Am was excreted (Fig. 3). Approximately 90 to $100 \%$ of the total radionuclide excreted was found in the faeces indicating that the rapid loss phase corresponded to the non-assimilated fraction which was eliminated via the digestive tract. Following the third day, faeces contained far less ${ }^{241} \mathrm{Am}$ and during the third-fourth weeks thereafter, radioactivity in

Table 2. Octopus vulgaris. Concentration ( $\mathrm{mBq} \mathrm{g}^{-1}$ wet) and distribution $(\%)$ of ${ }^{237} \mathrm{Pu}$ and ${ }^{241}$ Am in the tissues following $10-\mathrm{d}$ exposure in contaminated sea water and 70-d elimination period in running sea water. Two individuals were dissected for each radionuclide and their tissues grouped for radioanalysis ( $n$. d.: not detectable. $1 \mathrm{mBq} \sim 27 \cdot 10^{-3} \mathrm{pCi}$ )

\begin{tabular}{|c|c|c|c|c|c|}
\hline \multirow[t]{2}{*}{ Tissue } & \multirow{2}{*}{$\begin{array}{l}\text { Average } \% \text { total } \\
\text { tissue wet weight }\end{array}$} & \multicolumn{2}{|c|}{${ }^{237} \mathrm{Pu}$} & \multicolumn{2}{|c|}{${ }^{241} \mathrm{Am}$} \\
\hline & & $\mathrm{mBq} \mathrm{g}^{-1}$ wet & $\begin{array}{c}\% \text { of total } \\
\text { body burden }\end{array}$ & $\mathrm{mBq} \mathrm{g^{-1 }}$ wet & $\begin{array}{c}\% \text { of total } \\
\text { body burden }\end{array}$ \\
\hline Branchial hearts and appendages & 0.3 & 162000 & 87.6 & 3000000 & 98.8 \\
\hline Hepatopancreas & 2.7 & 130 & 0.4 & 330 & 0.1 \\
\hline Ventricle & 0.2 & n.d. & - & n.d. & - \\
\hline Gonad & 0.9 & n.d. & - & 560 & 0.05 \\
\hline Kidney & 0.8 & 1260 & 1.2 & 1110 & 0.1 \\
\hline Digestive tract & 2.7 & n.d. & - & 390 & 0.1 \\
\hline Gill and branchial gland & 1.8 & 1260 & 3.1 & 1670 & 0.3 \\
\hline Mantle & & & & & \\
\hline - epithelium & 2.9 & 170 & 0.7 & 110 & 0.05 \\
\hline - muscle & 7.5 & 80 & 0.5 & 60 & 0.05 \\
\hline Remainder (arms and cephalic body) & 80.2 & 80 & 6.5 & 60 & 0.5 \\
\hline
\end{tabular}




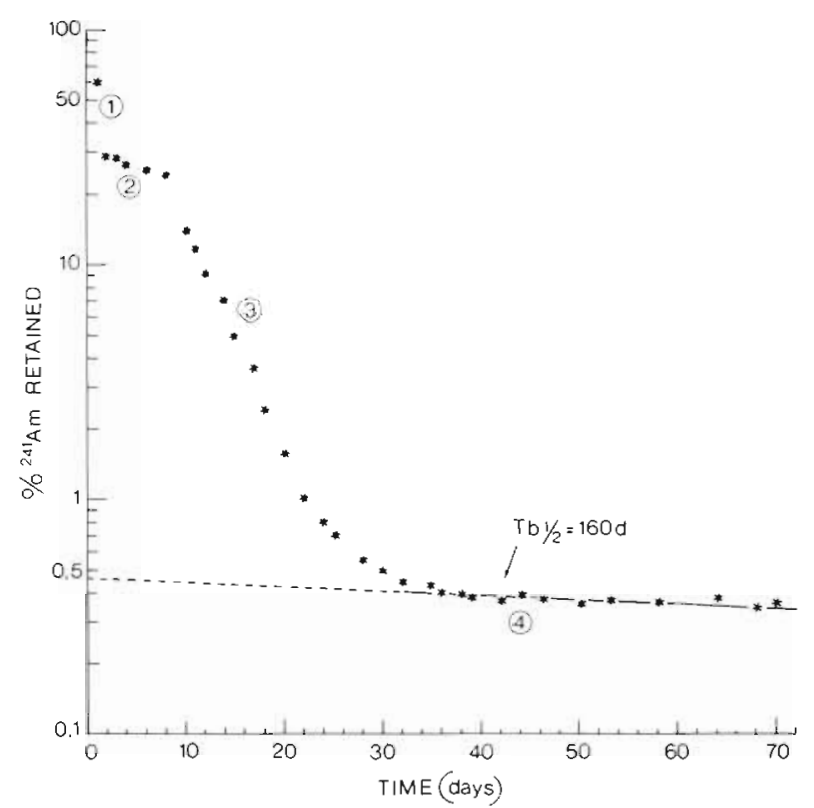

Fig. 4. Octopus vulgaris. Different phases of ${ }^{241} \mathrm{Am}$ excretion following a single ingestion of labelled crab. Symbol: mean value of 2 individuals

faeces represented no more than 35 to $50 \%$ of the total ${ }^{241}$ Am eliminated.

The second loss phase seen in Fig. 3 corresponded to excretion of the fraction of assimilated ${ }^{241} \mathrm{Am}$ by Octopus vulgaris. The assimilation coefficient was computed by extrapolating the linear portion of the curve (between Day 1-2 and 8-10) to the Y axis. Estimates made in this fashion range between 15 and $58 \%$ with an average value of $33 \%$. Elimination rates based on regression equations for the linear portion of the curves indicate that the assimilated fraction of ${ }^{241} \mathrm{Am}$ is excreted with an average biological half-time of $17 \mathrm{~d}$ (range 10-39 d).

It is noteworthy that after the 8 th to 10 th day, the ${ }^{241} \mathrm{Am}$ elimination rate in all individuals increased considerably (Fig. 3). By Day 30 only 2 individuals remained. These were maintained for a further $40 \mathrm{~d}$ to follow whole-body excretion. The data in Fig. 4 show the presence of an extremely slow loss phase $\left(\mathrm{Tb}_{1 / 2}=\right.$ 160 d) from a pool which represents about $0.5 \%$ of the incorporated radioactivity. This fraction of ${ }^{241} \mathrm{Am}$ may be associated with a single radionuclide pool or tissue within the octopus.

Dissection of 6 individuals during the excretion phase permitted identifying the sites of ${ }^{241} \mathrm{Am}$ binding within the octopus (Table 3). In the individual dissected $5 \mathrm{~d}$ after ingestion, $i$. e. during the second phase of loss, high concentrations of ${ }^{241} \mathrm{Am}$ were found in the hepatopancreas (158 $\mathrm{Bq} \mathrm{g}^{-1}$ wet) and the chitinous beaks ( $340 \mathrm{~Bq} \mathrm{~g}^{-1}$ wet), the latter of which are used to masticate the prey. It is interesting that the beaks lost

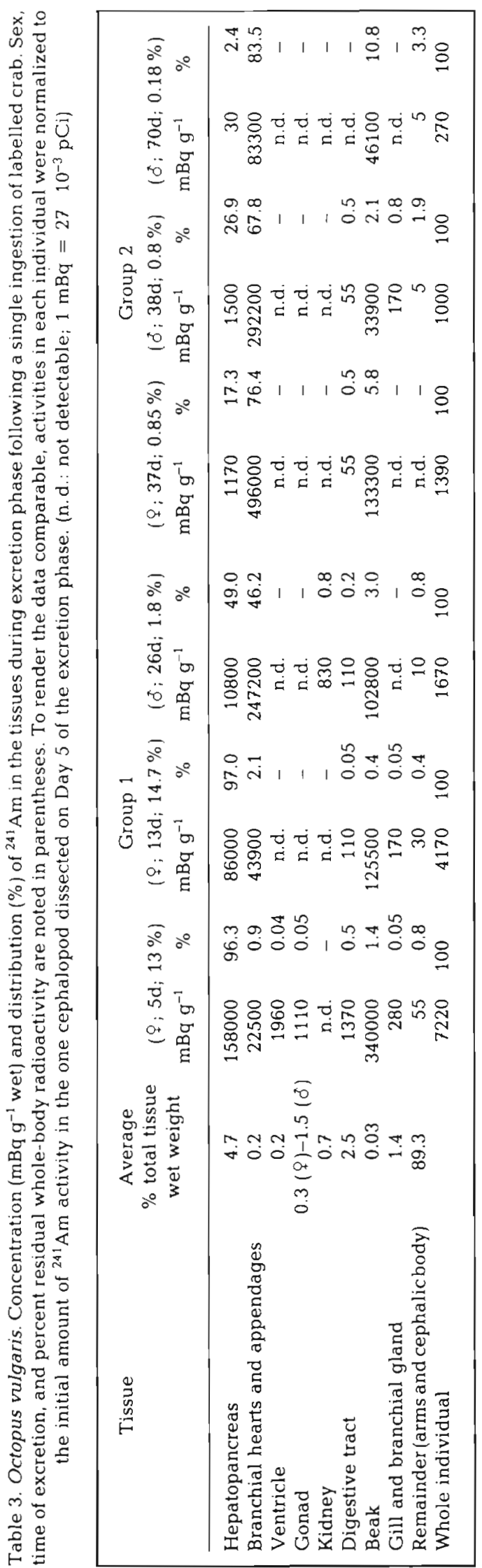




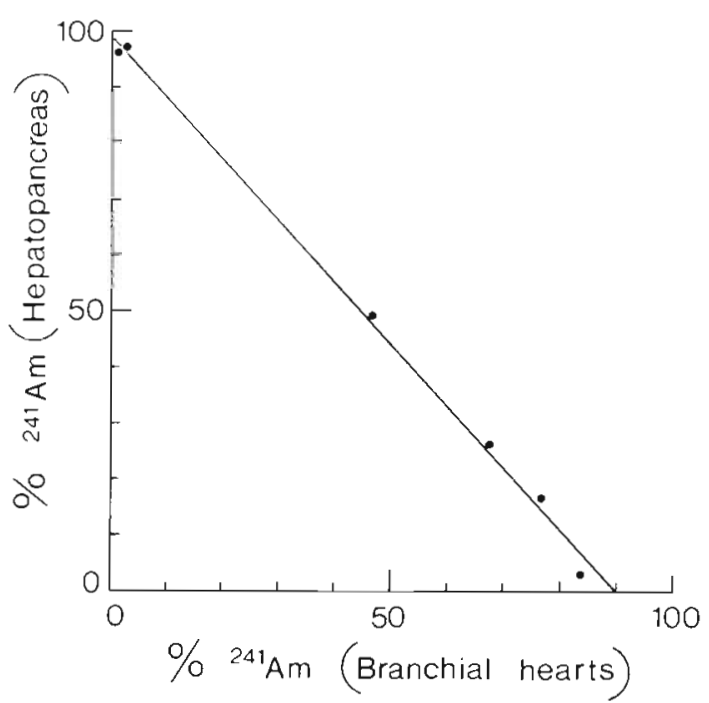

Fig. 5. Octopus vulgaris. Relationship between the fraction of whole-body ${ }^{241} \mathrm{Am}$ content in hepatopancreas and branchial hearts at different times during excretion phase following a single ingestion of labelled crab. Regression equation: $y=$ $98.84-1.089 x$

relatively little of their ${ }^{241} \mathrm{Am}$ activity throughout the depuration period; this probably resulted from strong binding of ${ }^{241} \mathrm{Am}$ to the chitinous matrix. The hepatopancreas which represents about $5 \%$ of the total cephalopod weight accounted for $96 \%$ of the ${ }^{241} \mathrm{Am}$ activity $5 \mathrm{~d}$ after ingestion. At the same time small, but significant amounts of ${ }^{241}$ Am were found in the branchial hearts, gonads, ventricle and digestive tract.

Following Day 5 the concentration of ${ }^{241} \mathrm{Am}$ in the hepatopancreas decreased continually reaching $0.03 \mathrm{~Bq} \mathrm{~g}^{-1}$ on Day 70 . The fraction of ${ }^{241} \mathrm{Am}$ retained in this organ likewise decreased from $96 \%$ to $2.4 \%$ at the termination of the experiment. These observations indicate that the radionuclide was lost much more rapidly from hepatopancreas than from the other tissues. Interestingly, the only cephalopod organs truly implicated in the process of metabolic excretion are branchial hearts (Bidder, 1966). This undoubtedly accounts for the concomitant increase in ${ }^{241} \mathrm{Am}$ concentration noted in these tissues during the experiment (Table 3). In fact there is a strong inverse correlation between the fraction of ${ }^{241} \mathrm{Am}$ held in these 2 tissues at different times during the excretion phase (Fig. 5).

The biokinetics of ${ }^{241} \mathrm{Am}$ in hepatopancreas, branchial hearts and whole octopus following ingestion of labelled food are illustrated in Fig. 6. It is evident that ${ }^{241} \mathrm{Am}$ is removed from the hepatopancreas 2 to 3 times more rapidly than from the whole body. This implies that a portion of the ${ }^{241} \mathrm{Am}$ lost from the hepatopancreas is transferred to other tissues, in this case the branchial hearts. The data in Fig. 6 show that this

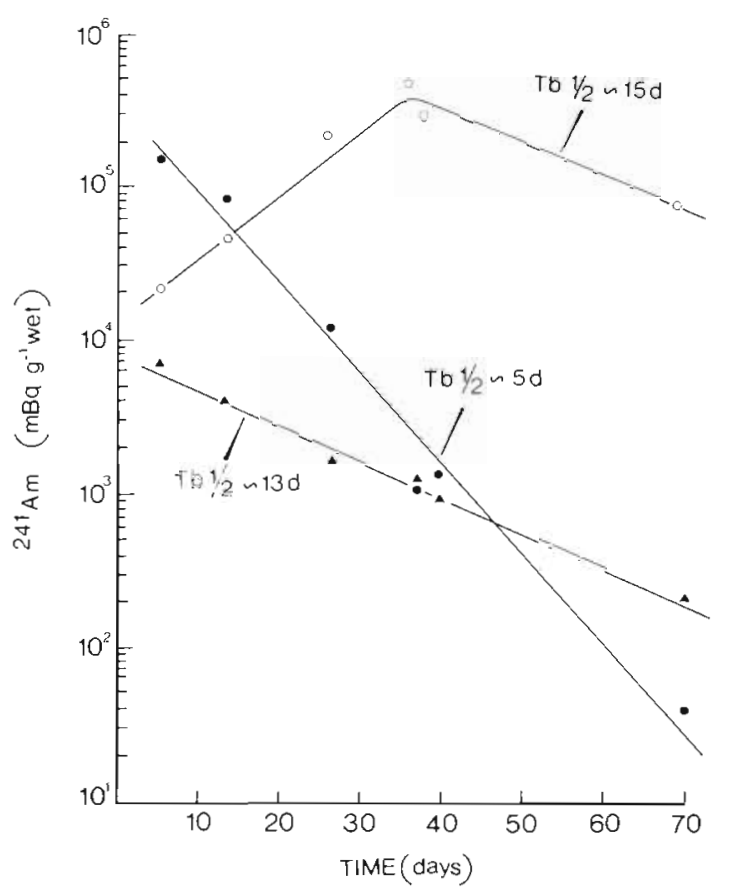

Fig. 6. Octopus vulgaris. Variation in the relative concentration of ${ }^{241} \mathrm{Am}$ in branchial hearts $(O)$, hepatopancreas $(\bullet)$ and whole individuals (4) during excretion phase following a single ingestion of labelled crab. All values are normalized to the ${ }^{241} \mathrm{Am}$ activity ingested by the first octopus $(16.4 \mathrm{kBq}$; $440 \mathrm{nCi})$ dissected on Day 5 of excretion. $(1 \mathrm{mBq}=$ $\left.27 \cdot 10^{-3} \mathrm{pCi}\right)$

transfer takes place from the time the radionuclide is assimilated until the 35th to 40th day, a period which corresponds to the end of the third phase of wholebody loss (Fig. 4). Following this transfer, the branchial hearts, which have concentrated ${ }^{241} \mathrm{Am} 200$ to 300 times over that in hepatopancreas, begin to eliminate the radionuclide approximately 3 times more slowly than the hepatopancreas. This period corresponds to the fourth phase of excretion noted in whole individuals (Fig. 4). However, since loss of this small fraction of ${ }^{241} \mathrm{Am}$ from whole octopus proceeds very slowly $\left(\mathrm{Tb}_{1 / 2}\right.$ $=160 \mathrm{~d}$ ), it would appear that excretion from the branchial hearts is not the sole factor controlling whole-body elimination of the small amount of ${ }^{241} \mathrm{Am}$ remaining. The dissection data in Table 3 show that ${ }^{241} \mathrm{Am}$ is strongly retained by the beak. This suggests that ${ }^{241} \mathrm{Am}$ retention by the beak was probably a significant factor in controlling the whole-body elimination rate after most of the radionuclide had been depurated from the octopus

\section{DISCUSSION}

Whereas bivalve and gastropod molluscs have been widely used as bioindicators for many types of pollut- 
ants, including radionuclides, cephalopods have only recently been examined in this context (Nakahara et al., 1979; Miramand and Guary, 1980, 1981; Guary et al., 1981). It is noteworthy that despite some similarities between cephalopods and bivalves in the pattern of whole-body uptake of transuranic elements, there are striking differences in their subsequent metabolism. For example, whole-body concentration factors for both ${ }^{237} \mathrm{Pu}$ and ${ }^{241} \mathrm{Am}$ in octopus are very similar to those reported for mussels exposed to these radionuclides under identical conditions (Fowler et al., 1975; Guary, 1980). In mussels approximately $90 \%$ of the radionuclides were fixed to shell which comprised $70 \%$ of the animal's weight. Furthermore, none of the internal tissues examined took up either radionuclide to any great degree. In contrast, cephalopods (with no shells) effectively accumulate and distribute ${ }^{237} \mathrm{Pu}$ and ${ }^{241} \mathrm{Am}$ among the internal tissues, especially the branchial hearts. Concentration factors of nearly $10^{4}$ were found in the branchial hearts with a slight preference for ${ }^{237} \mathrm{Pu}$ over ${ }^{241} \mathrm{Am}$ evident (Table 1). This is in good agreement with the similarly high concentration factors computed from environmental measurements of transuranic elements in octopus tissues (Guary et al., 1981). The branchial hearts have also been implicated in the uptake of ${ }^{137} \mathrm{Cs}$ (Suzuki et al., 1978), ${ }^{60} \mathrm{Co}$ (Nakahara et al., 1979) and certain heavy metals (Miramand and Guary, 1980); they would appear to be ideal organs for use as bioindicators for these types of contaminants, also given the wide distribution of the cephalopod in coastal zones throughout the world. The preference for ${ }^{237} \mathrm{Pu}$ over ${ }^{241} \mathrm{Am}$ in this tissue as well as others is also of interest since both field and laboratory studies have often demonstrated the opposite behaviour in many marine species including molluscs (Grillo et al., 1981; Pentreath, 1981).

The unique ability of the branchial hearts to concentrate many elements, including plutonium and americium, to such high levels may be linked to the biochemical nature of the circulatory and excretory functions of these organs. Nardi and Steinberg (1974) have shown that branchial hearts contain iron at concentrations ranging from 0.1 to $0.3 \%$ of their dry weight. The metal is localized in intracellular granules composed of a brownish-purple pigment whose precise physiological role is still unknown. These pigment bodies, or adenochromes (Fox and Updegraff, 1943), have been described in several species of Octopus and represent about $12 \mathrm{mg} \mathrm{g}^{-1}$ wet weight of the branchial hearts (Palumbo et al., 1977). Synthesis takes place in a leucopoietic organ lodged in the optic capsule (Cowden, 1972) in the form of iron-free precursors, or desferriadenochromes. It has been shown that other tissues of octopus such as gills and branchial glands, ovaries, hepatopancreas and kidney, as well as the amoebo- cytes, also contain small amounts of adenochromes.

Given the correlation between the presence of ironrich adenochromes and the high concentration of plutonium, americium and other radionuclides and stable metals in cephalopod tissues, Miramand and Guary (1981) used autoradiographic techniques to demonstrate the close association of ${ }^{241} \mathrm{Am}$ with adenochromes in the branchial hearts; nevertheless, they did not identify the exact nature of the radionuclide binding mechanism. It is most probable that the adenochromes of the branchial hearts of octopus are implicated in a process of detoxification of heavy metals comparable to those described for other molluscs (Martoja et al., 1977; Coombs and George, 1978; George et al., 1980). Furthermore, evidence for the presence of numerous pinocytotic vesicules in the cell membranes of the branchial hearts (Guary, 1980) and information on ferritin transport through the same organs in the cuttlefish Sepia officinalis (Schipp and Hevert, 1979) suggest that these radionuclides could be transported by pinocytosis, either free or fixed to adenochromes of the amoebocytes which originate in the gills and circulate in the haemolymph.

When experimentally-labelled cephalopods are transferred to clean seawater, ${ }^{237} \mathrm{Pu}$ and ${ }^{241} \mathrm{Am}$ are depurated only very slowly. Furthermore, the rate of loss of ${ }^{241} \mathrm{Am}$ tends to decrease with longer exposure times (Fig. 2). At the same time there is an increase in the size of the slowly exchanging ${ }^{241} \mathrm{Am}$ pool $(46 \%$ to $90 \%$ ) in the octopus as the exposure time increases from 10 to $22 \mathrm{~d}$. This phenomenon has been noted previously for heavy metals in bivalve molluscs and is thought to be a function of the time necessary for the metal or radionuclide to become firmly bound within internal tissues of invertebrates (Van Weers, 1973). Our data indicate that even after relatively short exposure (10 d) biological half-times for subsequent turnover can be as long as $1.5 \mathrm{yr}$ for the elimination of a substantial fraction of both radionuclides, the majority of which reside in the branchial hearts. This long depuration time is to be compared with the average lifespan of 2 to $4 \mathrm{yr}$ reported for Octopus vulgaris (Mangold-Wirz, 1963).

When contaminated food is ingested, ${ }^{241} \mathrm{Am}$ is efficiently assimilated $(\overline{\mathrm{X}}=33 \%)$ into the tissues of Octopus vulgaris. This assimilation coefficient is of the same order of magnitude as that measured for plutonium in crabs (Fowler and Guary, 1977) but is 30 times higher than coefficients for plutonium in fish (Eyman and Trabalka, 1977; Pentreath, 1978a, b) and 300 to 3000 times those of transuranic nuclides in mammals (ICRP, 1972; Durbin, 1975). The high degree of ${ }^{241} \mathrm{Am}$ assimilation in $O$. vulgaris may be linked to the high food conversion efficiency $(52 \%)$ reported for this species (Mangold and Boletzky, 1973). 
Following assimilation, ${ }^{241} \mathrm{Am}$ is rapidly concentrated to a high degree in the hepatopancreas. Before reaching the hepatopancreas the contaminated food bolus must pass successively through the digestive tract organs, viz. oesophagus, crop, stomach and caecum (Bidder, 1966). The latter organ is mainly secretory in function but is also involved in absorptive processes (Boucaud-Camou et al., 1976). Caecal fluid is expelled by contraction into the hepatopancreatic canals and reaches the digestive gland 4 to $6 \mathrm{~h}$ after feeding (Bidder, 1957). Furthermore, contrary to the function of the digestive gland of some cephalopods, the hepatopancreas of Octopus vulgaris is also an absorptive organ (Bidder, 1957). Each hepatic cell can successively secrete enzymes, absorb food material and finally excrete wastes. During absorption the cell becomes ciliated and accumulates fluids in the vacuoles. During the excretion phase, it accumulates 'brown bodies' which are then extruded into the lumen of the digestive gland and finally removed with the faeces.

According to Bidder (1966) the entire digestive process is completed within 15 to $20 \mathrm{~h}$ post ingestion. During this time our data show that the fraction of nonassimilated ${ }^{241} \mathrm{Am}$ is rapidly eliminated from the intestine (cf. Figs. 3 and 4). The assimilated fraction accumulates in the hepatopancreas and is then slowly excreted for the next 8 to $10 \mathrm{~d}$. Although it has not been demonstrated that ${ }^{241} \mathrm{Am}$ is associated with the excretory products termed 'brown bodies', it is likely that the radionuclide in the faeces has followed the same excretory route. Nevertheless, during the course of the experiment, a fraction of the assimilated ${ }^{241} \mathrm{Am}$ was transferred from hepatopancreas to the branchial hearts, the latter in which ${ }^{241} \mathrm{Am}$ concentration increased until the 35th to 40th d and then slowly decreased (Fig. 6). At this time whole-body excretion entered a slower phase (Fig. 4) with most of the elimination taking place from the branchial hearts.

If the hepatopancreas is principally responsible for the excretion of wastes, some explanation is needed to account for the partial transfer of ${ }^{241}$ Am to the branchial hearts before being eliminated. It is known that the branchial hearts of Octopus vulgaris contain high concentrations of adenochromes. According to Nardi and Steinberg (1974) these pigments show a strong affinity for iron and thus can be considered as natural complexing agents. Moreover, their presence throughout the body of the cephalopod (Nardi and Steinberg, 1974; Palumbo et al., 1977) suggests that they carry out some specific physiological function. It has also been shown that these pigments can be transported to various organs by way of amoebocytes (Palumbo et al., 1977). As mentioned previously, the transuranic elements as well as vanadium and cobalt could have a strong affinity for adenochromes; we suggest that the mechanism of ${ }^{241} \mathrm{Am}$ transfer between organs is related to its chemical affinity for these natural chelators. Hence ingested ${ }^{241} \mathrm{Am}$ entering the hepatopancreas with the caecal fluid would be able to complex with adenochromes carried by the amoebocytes that are present in the capillary network of the digestive gland. A substantial fraction of the ${ }^{241} \mathrm{Am}$ may not be complexed, because the quantity of adenochromes in this organ is low (Palumbo et al,, 1977). This non-complexed fraction would thus be excreted directly into the intestine during the cellular excretion phase, probably in association with the 'brown bodies'. On the other hand, the adenochrome-associated ${ }^{241} \mathrm{Am}$ fraction would not be directly eliminated because, contrary to the case with most molluscs, amoebocytes in the haemolymph of $O$. vulgaris are not excreted from the body (Wells, 1978). Therefore this fraction of ${ }^{241} \mathrm{Am}$ is rapidly transported to the branchial hearts by the anterior and lateral vena cava from which it is slowly eliminated (cf. Fig. 6).

In the case in which contamination occurs via the foodchain, this process is of secondary importance since the hepatopancreas is capable of excreting the majority of the assimilated radioelement directly into the intestine. In fact, adenochrome-associated ${ }^{241} \mathrm{Am}$ transfer would involve only a small part of the overall radionuclide depuration from the octopus, and then only because some adenochromes in the hepatopancreas inadvertently trap a portion of the available ${ }^{241} \mathrm{Am}$. On the other hand, transport via the amoebocytes, notably after complexation with adenochromes in the gills, would be of most importance in the case of an acute exposure to ${ }^{241} \mathrm{Am}$ in contaminated seawater. Rapid transport to the branchial hearts would thereby reduce the chances of a toxic buildup of these heavy elements in more sensitive tissues such as gill.

The presence of adenochromes in the renal sacs of Octopus vulgaris (Nardi and Steinberg, 1974) and the small fraction $(0.1-0.5 \%)$ of ${ }^{237} \mathrm{Pu}$ and ${ }^{241} \mathrm{Am}$ that were found associated with these tissues (Table 1) suggest that the excretion of transuranics from the branchial hearts could take place through the basal membrane of these organs in the direction of the pericardial coelom and the renal sacs. This route of elimination corresponds to the natural process of metabolic waste excretion in cephalopods which has been fully described by Harrison and Martin (1965) and Witmer and Martin (1973).

Acknowledgements. The International Laboratory of Marine Radioactivity operates under a tripartite agreement between the International Atomic Energy Agency, the Government of the Principality of Monaco and the Oceanographic Institute at Monaco. Support for the present work is gratefully acknowledged. 


\section{LITERATURE CITED}

Beasley, T. M., Cross, F. A. (1980). A review of biokinetic and biological transport of transuranic radionuclides in the marine environment. In: Hanson, $W$ C. (ed.) Transuranic elements in the environment. Technical Information Center, U.S. Department of Energy, Springfield, Va., pp. $524-540$

Bidder, A. M. (1957). Evidence for an absorptive function in the liver of Octopus vulgaris. Lam. Publ. staz. Zool. Napoli 29: 139-150

Bidder, A. M. (1966). Feeding and digestion in cephalopods. In: Wilbur, K. M., Yonge, C. M. (eds.) Physiology of mollusca. Academic Press, New York, pp. 97-124

Boucaud-Camou, E., Boucher-Rodoni, R., Mangold, K. (1976). Digestive absorption in Octopus vulgaris (Cephalopoda: Octopoda). J. Zool. 179: 261-271

Comar, C. L. (1955). Radioisotope in biology and agriculture, principles and practice, MacGraw-Hill, New York

Coombs, T. L., George, S. G. (1978). Mechanisms of immobilization and detoxication of metals in marine organisms. In: McLusky, D. S., Berry, A. J. (eds.) Physiology and behaviour of marine organisms. Pergamon Press, Oxford, pp. $179-187$

Cowden, R. R. (1972). Some cytological and cytochemical observations on the leucopoietic organs, the white bodies', of Octopus vulgaris. J. Invertebr. Pathol. 19: $113-119$

Durbin, P. W. (1975). Plutonium in mammals: influence of plutonium chemistry, route of administration and physiological status of the animal on initial distribution and long-term metabolism. Health Phys. 29: 495-510

Eyman, L. D., Trabalka, J. R. (1977). Plutonium-237: comparative uptake in chelated and non-chelated form by channel catfish (Ictalurus punctatus). Health Phys. 32: 475-478

Fowler, S. W., Guary, J. C. (1977). High absorption efficiency for ingested plutonium in crabs. Nature, Lond. 226: $827-828$

Fowler, S. W., Heyraud, M., Beasley, T. M. (1975). Experimental studies on plutonium kinetics in marine biota. In: Impacts of nuclear releases into the aquatic environment. International Atomic Energy Agency, Vienna, pp. 157-177

Fox, D. L., Updegraff, D. M. (1943). Adenochrome, a glandular pigment in the branchial hearts of the octopus. Archs Biochem. 1: 339-356

George, S. G., Pirie, B. J., Coombs, T. L. (1980). Use of electron microscope $X$-ray analysis in the determination of detoxication mechanisms for heavy metals in shellfish. In: Albaiges, J. (ed.) Analytical techniques in environmental chemistry. Pergamon Press, Oxford, pp. 477-484

Grillo, M. C., Guary, J. C., Fowler, S. W. (1981). Comparative studies on transuranium biokinetics in sediment-dwelling invertebrates. In: Impacts of radionuclide releases into the marine environment. International Atomic Energy Agency, Vienna, pp. 273-291

Guary, J. C. (1980). Recherches sur les transferts et la fixation du plutonium, de l'américium et du neptunium dans le milieu marin. Thèse Doctorat d'Etat-Sciences, Univ. AixMarseille II

Guary, J. C., Fowler, S. W. (1981). Americium-241 and plutonium-237 turnover in mussels (Mytilus galloprovincialis) living in field enclosures. Estuar. coast. Shelf Sci. 12: $193-203$
Guary, J. C., Higgo, J. J. W., Cherry, R. D., Heyraud, M. (1981). High concentrations of transuranics and natural radioactive elements in the branchial hearts of the cephalopod Octopus vulgaris. Mar. Ecol. Prog. Ser 4: 123-126

Harrison, F. M., Martin, A. W (1965). Excretion in the cephalopod Octopus dofleini. J. exp. Biol. 42; 71-98

ICRP (1972). The metabolism of compounds of plutonium and other actinides. International Commission on Radiological Protection, Publ. Ser 19, Pergamon Press, Oxford

Mangold-Wirz, K. (1963). Biologie des céphalopodes benthiques et nectoniques de la mer Catalane. Vie et Milieu, 13 (Suppl.): 1-285

Mangold, K., Boletzky, S. W. (1973). New data on reproductive biology and growth of Octopus vulgaris. Mar. Biol. 19: 7-12

Martoja, M., Lhonoré, J., Elkaim, B. (1977). Accumulations de métaux et de particules minérales dans les tissus mous de la coque comestible Cerastoderma edule (Mollusque Eulamellibranche). Relation avec le milieu. C.r. hebd. Séanc. Acad. Sci., Paris 284 D: 1453-1456

Miramand, P., Guary, J. C. (1980). High concentrations of some heavy metals in tissues of the Mediterranean octopus. Bull. Environm. Contam. Toxicol. 24: 783-788

Miramand, P., Guary, J. C. (1981). Association of americium241 with adenochromes in the branchial hearts of the cephalopod Octopus vulgaris. Mar. Ecol. Prog. Ser. 4: $127-129$

Nakahara, M., Koyonagi, T., Ueda, T., Shimizu, C. (1979). Peculiar accumulation of cobalt- 60 by the branchial heart of Octopus. Bull. Japan. Soc. Sci. Fish. 45: 539

Nardi, G., Steinberg, H. (1974). Isolation and distribution of adenochrome(s) in Octopus vulgaris. Comp. Biochem. Physiol. 48 B: 453-461

Palumbo, A., Ito, S., Nardi, G., Prota, G. (1977). Isolation of possible biosynthetic precursor of adenochrome from the white bodies of Octopus vulgaris. Comp. Biochem. Physiol. 58 B: 353-356

Pentreath, R. J. (1978a). ${ }^{237} \mathrm{Pu}$ experiments with the plaice Pleuronectes platessa. Mar. Biol. 48: 327-335

Pentreath, R. J. (1978b). ${ }^{237} \mathrm{Pu}$ experiments with the thornback ray (Raja clavata). Mar. Biol. 48: 337-342

Pentreath, R. J. (1981). The biological availability to marine organisms of transuranium and other long-lived nuclides. In: Impacts of radionuclide releases into the marine environment. International Atomic Energy Agency, Vienna, pp. $241-272$

Schipp, R., Hevert, F. (1978). Distribution of copper and iron in some central organs of Sepia officinalis (Cephalopoda). A comparative study by flameless atomic absorption and electron microscopy. Mar. Biol. 47: 391-399

Suzuki, Y., Nakahara, M., Nakamura, R. (1978). Accumulation of cesium 137 by useful mollusca. Bull. Japan. Soc. Sci. Fish. 44: 325-329

Van Weers, A. W. (1973). Uptake and loss of ${ }^{65} \mathrm{Zn}$ and ${ }^{60} \mathrm{Co}$ by the mussel Mytilus edulis. In: Radioactive contamination of the marine environment. International Atomic Energy Agency, Vienna, pp. 385-401

Wells, M. J. (1978). Octopus. Physiology and behaviour of an advanced invertebrate, Chapman and Hall, London

Witmer, A., Martin, A. W. (1973). The fine structure of the branchial heart appendage of the cephalopod Octopus dofleini martini. Z. Zellforsch. 136: 545-568 